st. $37-73$

APR $21098^{\circ}$

ENGINEERING DATA TRANSMITTAL

Page 1 of 1

1. EDT 622712

\begin{tabular}{|l|}
\hline $\begin{array}{l}\text { 2. To: (Receiving organization) } \\
\text { Distribution }\end{array}$ \\
\hline 5. Proj./Prog./Dept./Div.: \\
TWRS \\
\hline
\end{tabular}

8. originator Remarks:

11. Receiver Remarks:
3. From: (Originating organization)

I. G. Papp, Numatec Hanford Corporation

6. Design Authority/ Design Agent/Cog. Engr.:
4. Related EDT No.:

NA

7. Purchase Order No.:

NA

9. Equip./Component No.:

NA

10. System/Bidg./Facility:

NA

12. Major Assm. Dwg. No.:

NA

13. Permit/Permit Application No.: NA

14. Required Response Date:

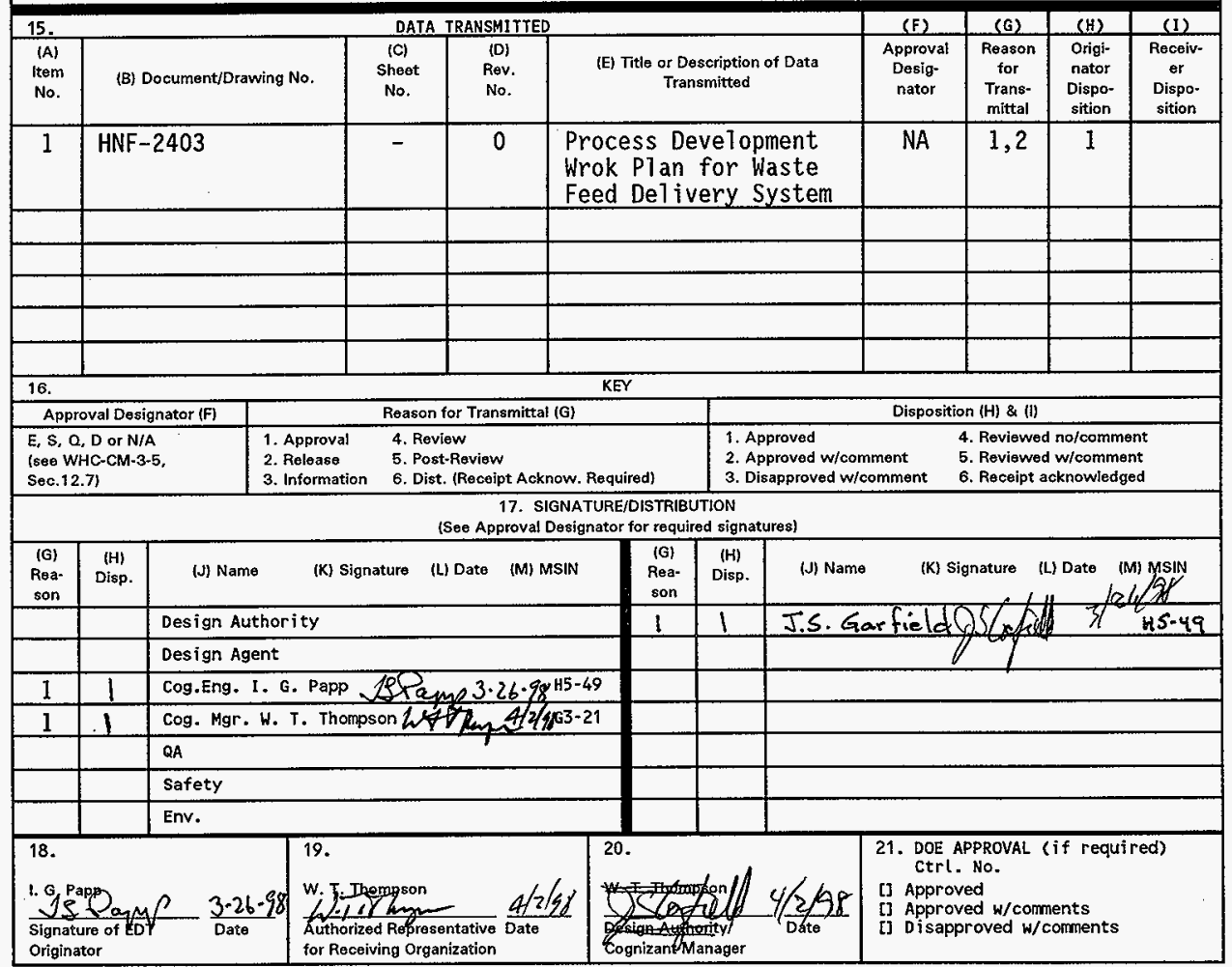




\title{
Process Development Work Plan for Waste Feed Delivery System
}

\author{
I. G. Papp
}

Numatec Hanford Corporation, Richland, WA 99352

U.S. Department of Energy Contract DE-AC06-96RL13200

$\begin{array}{llll}\text { EDT/ECN: } & \text { EDT } 622712 & \text { UC: } 721 \\ \text { Org Code: } & 73610 & \text { Charge Code: } & \text { D2D77 } \\ \text { B\&R Code: } & \text { EW3130010 } & \text { Total Pages: } 63\end{array}$

Key Words: work plan, waste feed delivery

Abstract: This work plan defines the process used to develop project definition for Waste Feed Delivery (WFD). Project definition provides the direction for development of definitive design media required for the ultimate implementation of operational processing hardware and software. Outlines for the major deliverables are attached as appendices.

TRADEMARK DISCLAIMER. Reference herein to any specific commercial product, process, or service by trade name, trademark, manufacturer, or otherwise, does not necessarily constitute or imply its endorsement, recommendation, or favoring by the United States Government or any agency thereof or its contractors or subcontractors.

Printed in the United States of America. To obtain copies of this document, contact: Document Control Services, P.O. Box 950, Mailstop H6-08, Richland WA 99352, Phone (509) 372-2420: Fax' (509) $376-4989$.
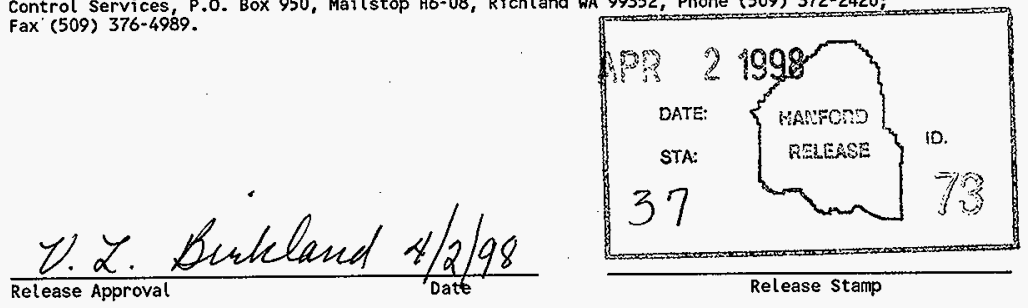

Approved for Public Release 
HNF-2403

Revision 0

\section{PROCESS DEVELOPMENT WORK PLAN FOR WASTE FEED DELIVERY SYSTEM}

March 1998

I. G. Papp

Numatec Hanford Corporation

Richland, Washington

Prepared for

U.S. Department of Energy

Richland, Washington 
HNF-2403

Revision 0

This page intentionally left blank. 
HNF-2403

Revision 0

CONTENTS

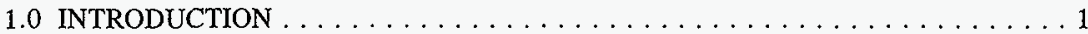

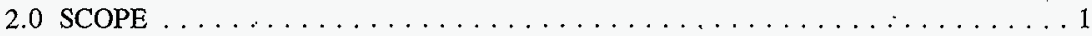

3.0 REQUIREMENTS ANALYSIS $\ldots \ldots \ldots \ldots \ldots \ldots \ldots \ldots$

3.1 DECISION SUMMARY/ALTERNATIVES GENERATION AND

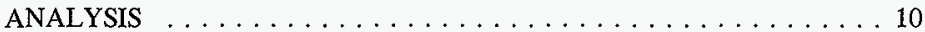

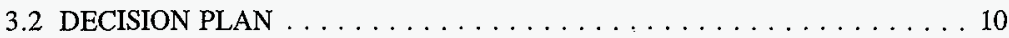

3.3 DEVELOPMENT OF DOUBLE-SHELL TANK SYSTEM

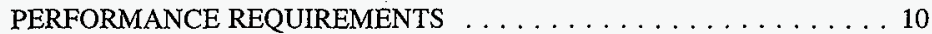

3.4 DEVELOPMENT OF PERFORMANCE REQUIREMENTS FOR

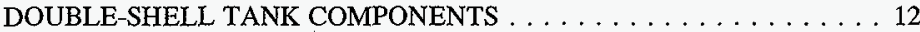

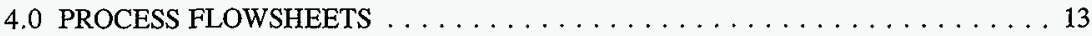

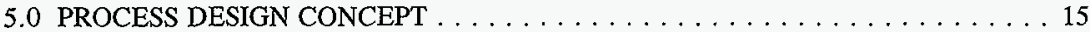

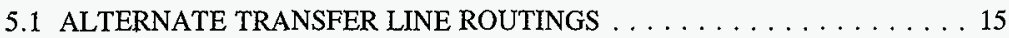

5.2 CONTROL SYSTEM INTEGRATION $\ldots \ldots \ldots \ldots \ldots \ldots \ldots \ldots$

5.3 MANIFOLD JUMPERS VERSUS RIGID $\ldots \ldots \ldots \ldots \ldots \ldots \ldots \ldots$

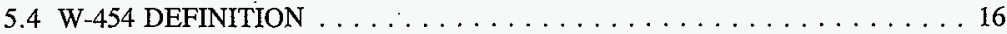

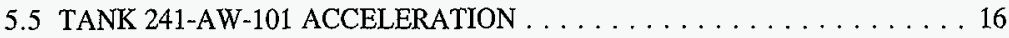

5.6 HIGH-LEVEL WASTE TANK / MIXER PUMP HEAT REMOVAL . . . . 16

5.7 ENCASED LINES THROUGH PIT WALLS $\ldots \ldots \ldots \ldots \ldots \ldots \ldots 17$

5.8 INVESTIGATE DEBRIS IN TANKS $\ldots \ldots \ldots \ldots \ldots \ldots \ldots \ldots$

5.9 REMOVAL AND DISPOSAL OF LONG LENGTH EQUIPMENT $\ldots \ldots \ldots 18$

5.10 STAGING TRANSFER EQUIPMENT STATUS $\ldots \ldots \ldots \ldots \ldots \ldots$

5.11 PUMP PIT DESIGN CONFIGURATION $\ldots \ldots \ldots \ldots \ldots \ldots \ldots \ldots$

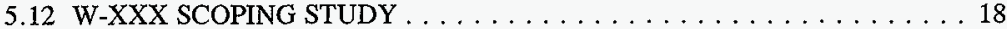

$5.13 \mathrm{~W}-211$ PNNL STUDIES INTEGRATION $\ldots \ldots \ldots \ldots \ldots \ldots \ldots$

5.14 UNDERGROUND INSTALLATION INVESTIGATION $\ldots \ldots \ldots \ldots 18$

5.15 BLANKING OLD ROUTES . . . . . . . . . . . . . . . 19

6.0 OPERATION AND MAINTENANCE CONCEPT PREPARATION $\ldots \ldots \ldots \ldots 21$

7.0 RELIABILITY, AVAILABILITY, MAINTAINABILITY/RISK ANALYSIS . . . . 23

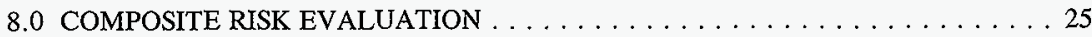

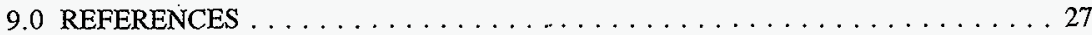


HNF-2403

Revision 0

APPENDIX

A - DOCUMENT OUTLINE PERFORMANCE REQUIREMENTS FOR PHASE 1 WASTE FEED DELIVERY COMPONENTS. . . . . . . . . A A-1

B - DOCUMENT OUTLINE TECHNICAL BASIS DOCUMENT. . . . . . . B-1

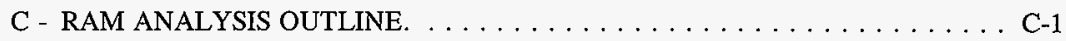

D - WASTE FEED DELIVERY SYSTEM (WFDS) COMPOSITE RISK ANALYSIS. D-1

\section{LIST OF FIGURES}

1. Waste Feed Delivery Project Definition Process. . . . . . . . . . . . . 3

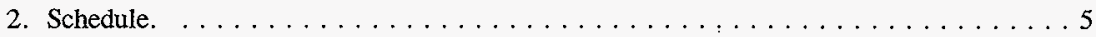

\section{LIST OF TABLES}

1. Proposed Double-Shell Tank Waste Feed Delivery Architecture. . . . . . . . . . . 11 
HNF-2403

Revision 0

\section{LIST OF TERMS}

AGA

DOE

DST

Ecology

FMEA

FY

HLW

$O \& M$

OWVP

PCP

PHMC

PNNL

RAM

SSC

TWRS

TWRSO\&UP

USQ

WAC

WFD

WFDS
Alternative Generation and Analysis

U.S. Department of Energy

Double-shell tank

Washington State Department of Ecology

Failure modes and effects analysis

Fiscal year

High-level waste

Operation and Maintenance

Operational waste volume projection

Project Control Plan

Project Hanford Management Contractor

Pacific Northwest National Laboratory

Reliability, availability, and maintainability

Systems, structures, and components

Tank Waste Remediation System

Tank Waste Remediation System Operation and Utilization Plan

Unreviewed Safety Question

Washington Administrative Code

Waste Feed Delivery

Waste Feed Delivery System 
HNF-2403

Revision 0

This page intentionally left blank. 
HNF-2403

Revision 0

\section{PROCESS DEVELOPMENT WORK PLAN FOR WASTE FEED DELIVERY SYSTEM}

\subsection{INTRODUCTION}

This work plan defines the process used to develop project definition for Waste Feed Delivery (WFD). Project definition provides the direction for development of definitive design media required for the ultimate implementation of operational processing hardware and software. Figure 1 lists the key documents associated with this effort. An identifier listed next to each section heading ties that section to the documents illustrated in Figure 1. Schedule durations for the major activities are shown in Figure 2. Outlines for the major deliverables are attached as appendices.

The implementation of hardware and software will accommodate requirements for safe retrieval and delivery of waste currently stored in Hanford's underground storage tanks.

Operations and maintenance ensure the availability of systems, structures, and components for current and future planned operations within the boundary of the Tank Waste Remediation System (TWRS) authorization basis. The operational strategy supporting the Phase 1 mission is in development and is based primarily on the operational scenario developed in the Tank Waste Remediation Systems Operation and Utilization Plan (TWRSO\&UP) (Kirkbride et al. 1997). Maintenance is and will continue to be based on the requirements established by DOE Order 4330.4B Maintenance Management Program, Chapter 2, "Nuclear Facilities." The TWRS Phase 1 maintenance strategy for Phase 1B of the WFD mission, is outlined in the Tank Waste Remediation System Program Plan (Freeman 1998). When the operational requirements are established to support the TWRS retrieval and disposal mission, the maintenance strategy will be revised to provide the best-value maintenance and logistics support throughout the operational life cycle of the mission.

\subsection{SCOPE}

The scope of this work plan is limited by the need to define an operating system capable of accommodating TWRS storage, retrieval, delivery, and ultimate closure missions. A Process Design Concept developed to illustrate Phase 1B of the WFD mission is the product of the effort described in this plan. Figure 1 illustrates the scope of this work plan and the interrelationship of the activities leading to the ultimate definition of the WFD System. 
-HNF-2403

Revision 0

This page intentionally left blank. 
WFD Project Definition Process 4/98 Documents WFD Eqpt Decision Plan \& Criteria 9/98 A. WFD Technical Basis Document Vol. I Summary

Flowsheet Vol. III WFD Process Design Concept Vol. IV WFD O\&M Concept 7/98 B. WFD RAM Analysis 8/98 C. WFD System Risk Analysis

D. DST Facility Specification

F. Project Conceptual Design Report

G. Project Design Criteria

DST $\approx$ Double-Shell Tank

O\&M $=$ Operations \& Maintenance
RAM $=$ Reliability, Availability, Maintainability

SSC $=$ Systems Structures \& Components
TWRSO\&UP $=$ TWRS Operation \& Utilization Plan 


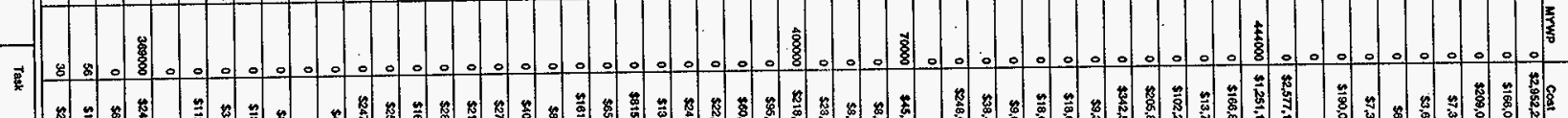

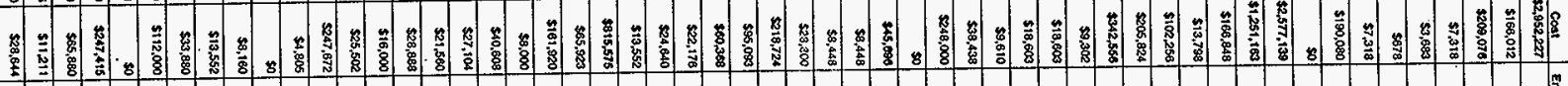

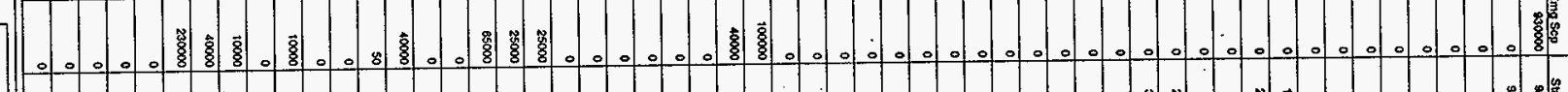

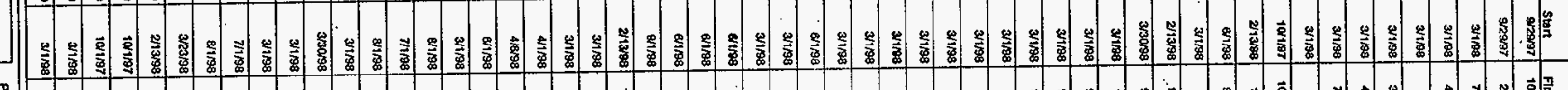

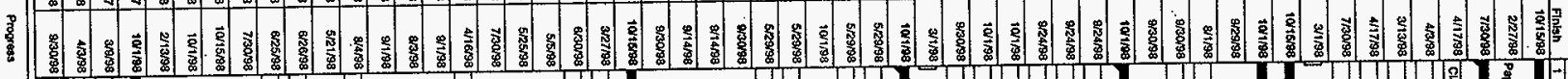

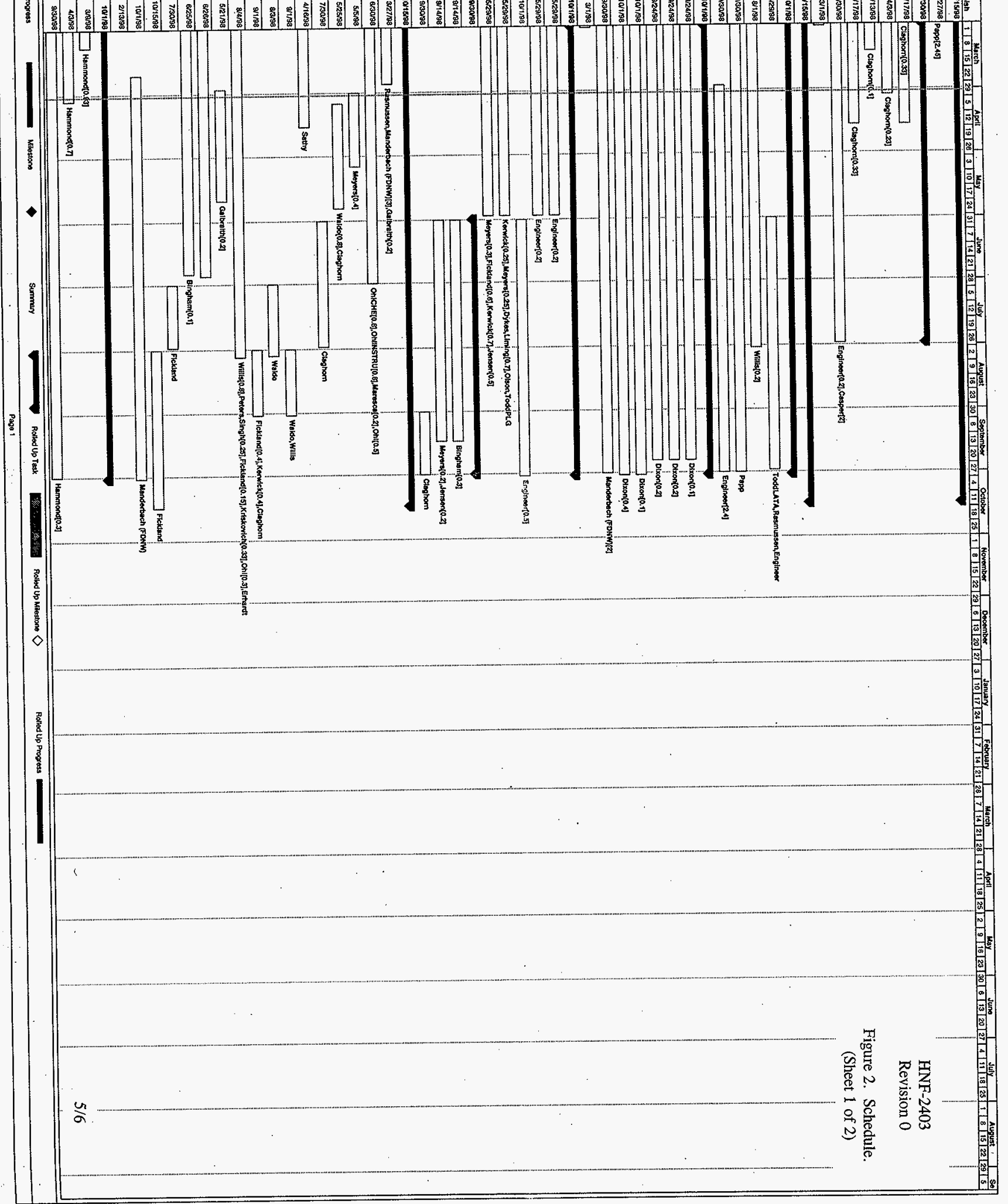




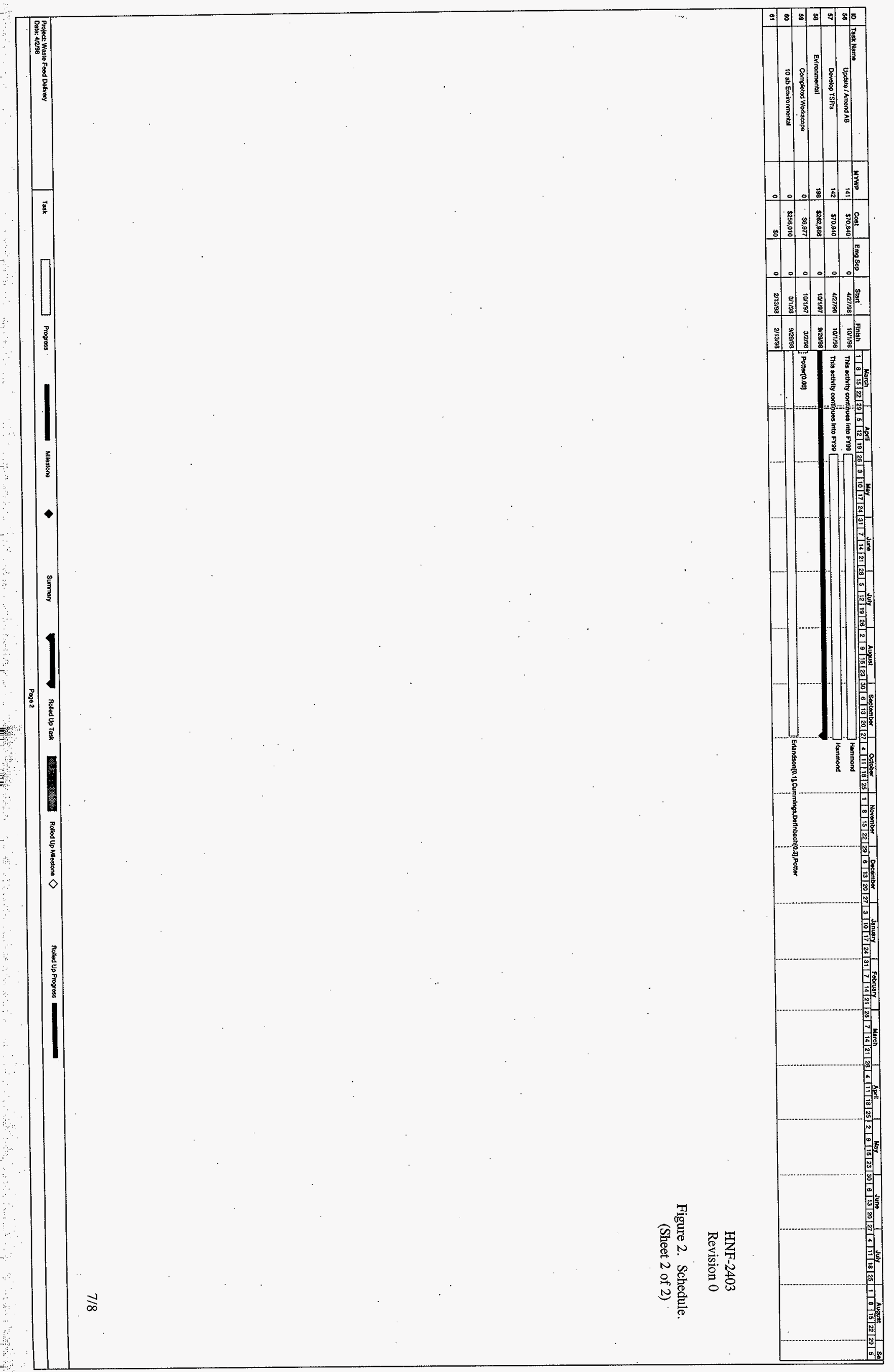


HNF-2403

Revision 0

\subsection{REQUIREMENTS ANALYSIS}

Process requirements are established to provide the boundary of system design and processing conditions to successfully carry out the WFD mission. Requirements are established by evaluation of waste properties and of physical and chemical capabilities and restraints that are inherent to existing TWRS systems, structures, and components (SSC) and which result from design of new SSC.

The WFD mission requirements are used to evaluate existing SSC. These SSC are inventoried and the operational status, in relation to the WFD mission is established through the application of engineering discipline, evaluation of performance against the TWRS Authorization basis, and evaluation of relevant environmental permitting issues, which are likely to govern the ultimate operation of the WFD System.

Requirements are based on several factors. These factors include Safety, Environmental Permitting, Process Engineering, Operations, Maintenance, Training, and Administration of the final TWRS facility.

The purpose of these requirements is to identify process requirements for components of the Double-Shell Tank (DST) System. Performance requirements for DST components will be used to verify that the existing design is adequate for those components that are existing or already in the design or procurement process. This version of the process requirements establishes requirements for the system components applicable to the first phase of the TWRS mission described in the Tank Waste Remediation System Mission Analysis (Acree 1998). It does not specify requirements for either the Phase 2 mission or the DST system closure period.

The requirements are prioritized to support: (1) technical issues surfacing in the ongoing project design; (2) identification of equipment needs not in the current projects; and (3) comprehensive coverage of performance requirements and the "parent" traceability to upper level specifications. Per items 1 and 2, an issues list will be maintained to track "missing" criteria needed for project action.

The performance requirements are issued in two parts: the one that feeds into the DST System Specification is the Performance Requirements for the Double-Shell Tank System: Phase 1 (Claghorn 1998), and the one that feeds into the tank-specific flowsheets is the Performance Requirements for Phase 1 Waste Feed Delivery Components (Claghorn et al. 1998). The requirements that are originally prepared are supplemented by future iterations of evaluations of the SSC and any new requirements that might surface. The evaluation of SSC is fine tuned by continuing efforts such as the RAM analysis and Risk'analysis. 


\subsection{DECISION SUMMARY/ALTERNATIVES GENERATION AND ANALYSIS}

This effort consists of summarizing the results of previous work such as decisions and alternatives generation and analysis (AGA) to facilitate a formal decision on the DST System architecture tree. The decision forms the basis for Section 3.7 of the DST System Specification. The procedure for this work is paragraph 5.6 of Section 2.7 (Decision Management) of the TWRS Administration manual (LMHC 1996).

Several decisions have been made regarding the major subsystems of the WFD architecture. Decisions have not been made, however, on the sludge washing system and smaller subsystems such as the electrical subsystem. This effort will compile all of the rationale supporting the development of the proposed architecture tree represented by Table 1 . A decision board may then be convened depending on the desire of the decision maker. The summary will then be presented to the decision maker (or board). The decision maker may determine that additional work is required before a decision can be made.

After these decisions have been made, then the program can "test" the system by performing a detailed analysis of the selected architecture to assure the program that the system will meet prescribed requirements.

\subsection{DECISION PLAN}

This effort (see Figure 1) consists of the development of a pian for determining the disposition of the results of the composite risk analysis. The plan will identify the decision(s) to be made, who makes the decision, and how the decision will be made. The "how" part of the decision is simply a summary of this (project definition) work plan. Most important, the criteria for making a decision will be enumerated in explicit terms. The procedure for this work is in paragraphs 5.1 through 5.3 of Section 2.7 (Decision Management) of the Tank Waste Remediation System Administration Manual (LMHC 1996).

\subsection{DEVELOPMENT OF DOUBLE-SHELL TANK SYSTEM PERFORMANCE REQUIREMENTS}

This effort consists of an analysis of the transfer information embedded in the TWRSO\&UP (Kirkbride et al.1997) as updated by the Tank Waste Remediation System Retrieval and Disposal Mission Initial Updated Baseline Summary (Swita 1998). The results of the analysis then become the basis for the performance requirements listed in Section 3.2.1 of the DST System Specification. The procedure for this work is Section 3.6 (Engineering Calculations) of the Tank Waste Remediation System Administration Manual (LMHC 1996). 
HNF-2403

Revision 0

Table 1. Proposed Double-Shell Tank Waste Feed Delivery Architecture.

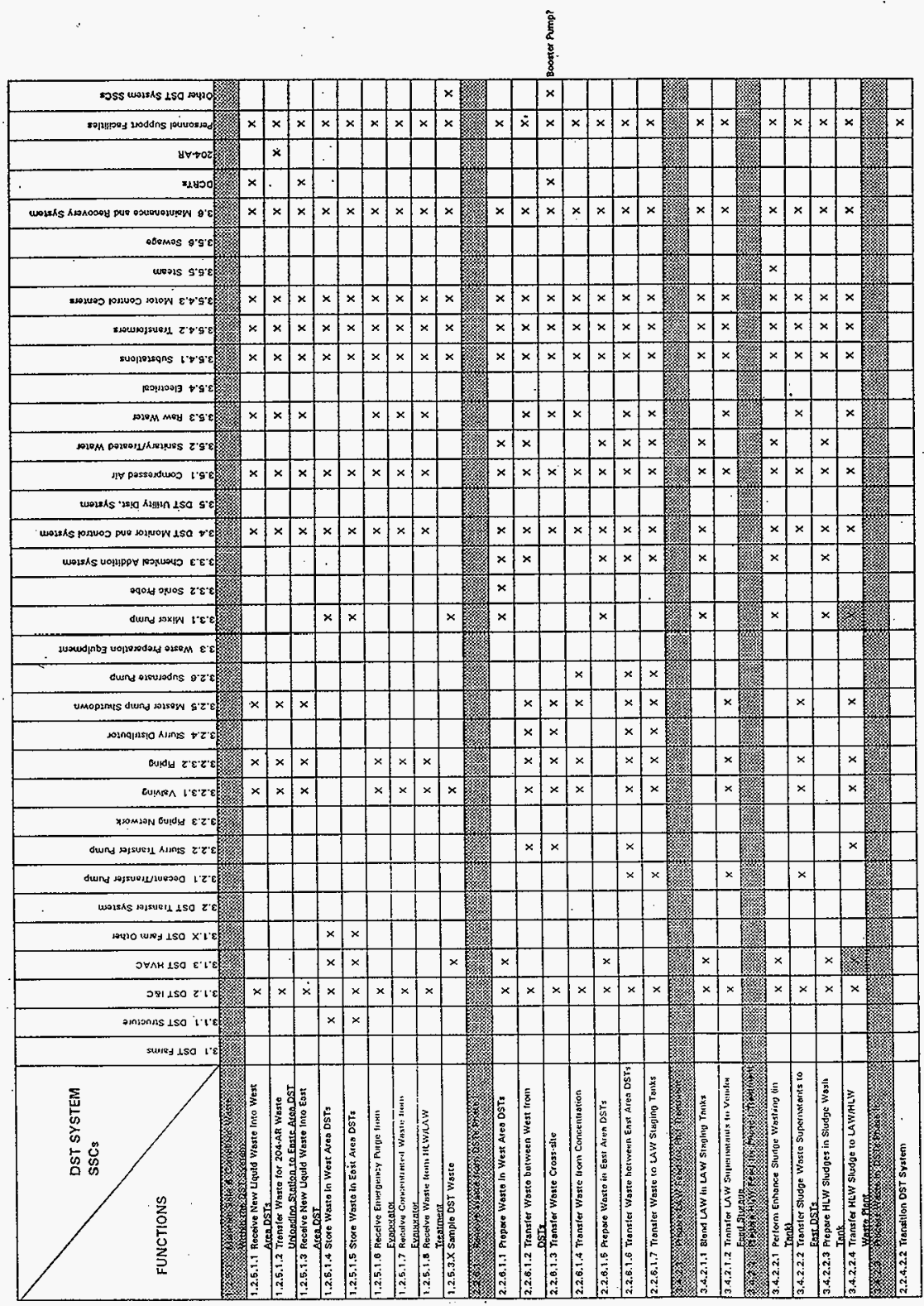


HNF-2403

Revision 0

\subsection{DEVELOPMENT OF PERFORMANCE REQUIREMENTS FOR DOUBLE-SHELL TANK COMPONENTS}

This effort consists of an analysis similar to the one described in Section 3.3. The results of this analysis, however, are presented in greater detail so that performance requirements can be allocated to individual components of the DST system. The results of the analysis then become the basis for the performance requirements listed in Section 3.2.1 of the DST Component Specification(s). 
HNF-2403

Revision 0

\subsection{PROCESS FLOWSHEETS}

The Phase 1 system flowsheets (see Figure 1, AII) are being prepared as part of a larger task defining the waste feed. The flowsheets are prepared on a tank specific basis. This means they are representative of the physical and chemical characteristics of the tank waste as it is retrieved through the various processing steps which apply to that particular source tank. The processing steps definitions are based on the waste characteristics of the specific tank in question.

Processing steps are developed and based on requirements which will ultimately condition the waste to a state suitable for transfer to the private vitrification facilities. Processing steps are developed by analysis of required functions for the particular waste tank being evaluated. Processing steps will be supported by the identification of processing components which aid in the monitoring and control of the processing steps. The supporting components will be identified by function and requirements for components will be developed. Requirements will specify the purpose of the component (i.e., required by environmental permitting, maintain authorization basis limits, provide process knowledge etc.). A set point selection basis document will be developed to provide the range of operations and alarm set points, which accompany each process parameter.

Stream attributes such as temperature, pressure, viscosity and density, are presented for a specific point or condition in the process sequence. Figures of the transfer system will accompany the flowsheet information as a representation of the overall transfer scenario related to that particular tank. However; the flowsheet will account for the total volume of retained gas that will be released as a result of disturbing the settled layer in these tanks, and the total radionuclide content. Otherwise, the flowsheet is on a rate basis. Stream attributes such as temperature, pressure, viscosity and density, are provided.

Heating requirements are addressed through pre-heating dilution water to achieve the desired temperature. Energy calculations also account for the heat of dissolution of the two primary salts: sodium carbonate (exothermic) and sodium nitrate (endothermic). 
HNF-2403

Revision 0

This page intentionally left blank. 
HNF-2403

Revision 0

\subsection{PROCESS DESIGN CONCEPT}

The Process Design Concept (see Figure 1, AIII) contains a complete description of what is known about the WFD system in relation to the existing TWRS facility SSC and planned project activities. This description also details the delta between existing facilities and projects required to meet the mission needs of the WFD system. The delta scope is derived from best engineering judgement which result from engineering studies of the various issues. The main focus of the Process Design Concept is the illustrations and narratives describing the given concept, systems, projects, designs, and modifications.

With each systems engineering iteration, this document will be updated and likely contain more detail as revisions are produced. The initial focus (fiscal year [FY] 1998) will be on development of the information surrounding the 241-AN-105, 241-AN-104, and 241-AZ-101 transfers.

Information on subsequent designs will be made available in future revisions as designs are produced. An outline of the document is attached and provides more description of each section included.

Several engineering studies will be conducted in support of the Process Design Concept. These studies are listed in the following sections of this work plan (deliverable September 30, 1998).

Engineering studies are required to complete the Process Design Concept. These studies will be used to fill in areas that require further design development or requirements' definition.

\subsection{ALTERNATE TRANSFER LINE ROUTINGS}

This stidy will investigate alternatives to the current baseline proposed by configuration of the W-211 and W-314. A preliminary study will identify the magnitude difference of the cost and/or risk. The preliminary investigation will determine the merit of continuing with further development of the Project Design Concept as related to the most optimum WFD system.

\subsection{CONTROL SYSTEM INTEGRATION}

Integration of the Existing TWRS control system with the new project installed control system components. This effort will determine the benefit of centralized control, multiple field controls or some amount of field and central control and monitoring. 


\subsection{MANIFOLD JUMPERS VERSUS RIGID}

Manifold jumpers with multiple valves were originally scoped in expense project W-314. This funding was dropped and the jumpers are planned for inclusion in W-314. Use of manifolds was originally thought to provide operations more flexibility to change routings (valve settings) without removing jumpers or pit cover blocks. This efficiency has to be balanced against the added complexity of a feed delivery transfer with over 150 valves to configure control and maintain.

\subsection{W-454 DEFINITION}

The scope of work required in the AW farm area of the East Tank Farms is needed to ensure all transfers scheduled for Envelope $A$ waste is accommodated. This effort includes the compilation of process expectations related to the transfers and the performance expectations related to the chemical and physical characteristics of the waste involved in the transfer.

\subsection{TANK 241-AW-101 ACCELERATION}

In the event that an equipment failure prevents transfer of feed from any of the first envelope A source tanks, fall-back position could be equipping 241-AW-101 with the W-211 upgrades so that an envelope $A$ tank from a different farm using different routings could be easily substituted. This anticipates a reliability, availability, and maintainability (RAM) finding that a work-around is needed to reduce risk of failing to deliver feed.

\subsection{HIGH-LEVEL WASTE TANK / MIXER PUMP HEAT REMOVAL}

The sludge washing effort in DSTs will require temperature control. If the waste is not heated, a component such as aluminum will exceed the waste feed specification. If the waste is heated too much, then the chemistry of the solids will no longer comply with the prescribed waste feed specifications. The equipment and the procedure required to control temperature is currently undefined and could be a factor in the selection of a sludge washing process.

The Heat Removal Analysis will evaluate alternative means for controlling the temperature in a high-level waste (HLW) sludge washing tank. The alternatives include various combinations of operating procedures, heat sources, heat sinks, and instrumentation.

The DOE/PHMC pretreatment objective is currently unknown at this time so there may be two analyses - one for each of two different objectives. These objectives are: (1) prepare HLW feed to meet contract specifications, and (2) minimize HLW glass. It is assumed that a simple water wash will not require the control of temperature other than to halt mixer operations before the waste reaches tank temperature limits. 
To initiate the analysis, a process must be specified for each of the two pretreatment objectives. The process specification defines the process steps and conditions. Various combinations of operating procedures, heat sources, heat sinks and instrumentation will then be generated for compliance with the process requirements and then screened for further study. Selected alternatives will be evaluated in sufficient detail such that a decision maker or a decision board can be convened to select a system. The decision analysis will review the available information and determine if there is sufficient information to make a decision. Once a decision has been made, then the technical detail will be finalized and a decision document will be written and issued.

\subsection{ENCASED LINES THROUGH PIT WALLS}

The task addresses potential issues relating to availability of the transfer lines and the compliance of the transfer lines with WAC-173-303. Both issues were developed for the primary transfer route and a potential alternate. The primary transfer route should be available. There is a potential issue with the compliance of the SN-650 line. The secondary containment of the SN-650 line does not penetrate the wall of the 241-A-B Valve Pit. The line may however be compliant because of the design of the interface with the A-B Valve Pit, and because the A-B Valve Pit is at the high point in the line. Negotiations with Washington State Department of Ecology (Ecology) (10/16/97) suggest that they are likely to accept the line as compliant. It is very important that this acceptance of the line (if granted) by Ecology be well documented. It seems very likely at this time that there will not be availability or compliance issues with the primary transfer route.

An alternate route has not yet been identified. The lines which would likely be identified as an alternate route have issues with both compliance and availability. At the completion of the W-314 Project, Some or all of the existing lines in the route from 241-AN-105 to 241-AP-102/104 will be placed into a "standby" condition. This may include capping the nozzles in the pump/valve pits and discontinuing periodic maintenance and calibration of leak detectors. If these lines were needed for feed delivery, it would require a significant effort to reactivate them. Additionally, at least two of the lines in the most likely alternate route (SN-201/214 and SN-220) are not compliant with WAC-173-303. The secondary containment piping of these lines does not penetrate the pump/valve pits at the ends of the lines. It may be possible to negotiate the use of these lines.

\subsection{INVESTIGATE DEBRIS IN TANKS}

A survey of tank debris will be compiled to document "Tribal Knowledge" of the tanks scheduled for transfer to support the WFD mission. This knowledge base is possessed by operation, maintenance and field personnel but is not accounted for in the activities required to complete a transfer. 
HNF-2403

Revision 0

\subsection{REMOVAL AND DISPOSAL OF LONG LENGTH EQUIPMENT}

This activity confirms that project upgrades of in-tank hardware (pumps, thermocouple trees, etc.) or failed in-tank hardware can be removed and disposed without impacting schedules or the operational availability.

\subsection{STAGING TRANSFER EQUIPMENT STATUS}

Waste movements that must be made prior to the feed deliver to open up the feed staging tanks (241-AP-102, 241-AP-104) and Vendor Feed Tanks (241-AP-106, 241-AP-108) are called bootstrap transfers. Similar HLW transfers are also required to move HLW solids to enable sludge washing and feed queuing. This activity assures that equipment is in place to accomplish these tasks on the schedule called for in the TWRSO\&UP/Operational Waste Volume Projection (OWVP) and the mid-level logic. Any gaps must be filled with a project or expense funded action.

\subsection{PUMP PIT DESIGN CONFIGURATION}

The pump configuration together with the pump pit equipment design in 241-AP-102, 241-AP-104, 241-AN-105, and 241-AZ-101 will be reviewed on a priority to assure that dilution and monitoring requirements are met. The design will maximize assurance against line plugging.

\subsection{W-XXX SCOPING STUDY}

Follow on activities for the W-211 Project will be identified to determine capital or expense related work to round out the balance of the WFD System.

\subsection{W-211 PNNL STUDIES INTEGRATION}

Current studies being conducted for the W-211 Project by Pacific Northwest National Laboratory (PNNL) will require integration with the investigations of the Process Development organization.

\subsection{UNDERGROUND INSTALLATIÒN INVESTIGATION}

This study will investigate alternate methods of surveying the underground installations in the area to be excavated in preparation for WFD related construction activities. It also will compile all relevant information related to the installations in an effort to consolidate information for future use. 
HNF-2403

Revision 0

\subsection{BLANKING OLD ROUTES}

Routes which are no longer in use may lead to future misroutings. Such misroutings would severely impact the ability to meet the WFD schedule. A survey of all such routes will be taken and the results compiled into a document for future reference, 
HNF-2403

Revision 0

This page intentionally left blank. 


\subsection{OPERATION AND MAINTENANCE CONCEPT PREPARATION}

The Operation and Maintenance (O\&M) Concept (see Figure 1, AIV) document will define the methodology for conducting operations and maintenance and accommodate the TWRS WFD operational scope. The O\&M Concept is preceded by an O\&M Concept Procedure. The procedure will define the process for continued O\&M Concept development.

The O\&M Concept will consider the installation of the operational control systems provided by TWRS projects as well as the integration of the existing monitor and control system. The O\&M concept will establish the range of operations which will allow operations to carry out the WFD mission. This range of operations will utilize all available components (new and existing) to establish a fully functional system capable of delivering waste through any of a number of possible transfer scenarios. The new control system will allow for a variety of automatic computer generated operational modes.

The O\&M concept will also accommodate the maintenance activities related to the new process systems being installed. This means providing allocation of resources capable of maintaining the WFD schedule of transfers to the private contractors. Engineering studies will support the identification of risk associated with the maintenance aspects and provide solutions for optimization of the maintenance activities. This will include the optimization of key activities such as the removal of long length equipment.

The TWRS operations organization has been tasked with preparing an O\&M Concept. The existing O\&M concept will be used for evaluation in the RAM analysis. Based on the outcome of the RAM, modifications to the O\&M may be made to optimize the total TWRS integrated operations. 
HNF-2403

Revision 0

This page intentionally left blank. 
$\mathrm{HNF}-2403$

Revision 0

\subsection{RELIABILITY, AVAILABILITY, MAINTAINABILITY/RISK ANALYSIS}

The RAM analysis (see Figure 1, B) of the WFD system will be developed as a set of values defining the efficiency expected to contribute to the operations of the finished system. The evaluation will be focused around the initial two low-level (241-AN-105/104) and high-level (241-AZ-101) tanks. A detailed breakdown of the work is included as Appendix C. Operational steps will be evaluated to develop a schedule-based figure of merit which reflects the current O\&M Concept. Optimization of the TWRS SSC and the O\&M concept will be implemented when a reduction of schedule risk can be cost effective (Deliverable 7/98).

Risk issues including but not limited to the following topics will be investigated: Constructability, Implementability, Processability, Operability, Licensability, and Permitability.

Constructability review will be based on design of the WFD System and the existing systems (such as existing piping design) and the failure of such components to meet the performance criteria.

Implementability is evaluated after the Process Design Concept loop can be exited and a Project Control Plan (PCP) developed. Risk associated with implementation of the design is minimized by comment resolution against the PCP.

Processability will be optimized through iterations of the Process Design Concept development phase. The ability to successfully establish processing steps to each tank is integrated with flowsheet development.

Operability development is performed in conjunction with the O\&M Concept preparation. The O\&M Concept falls out of the RAM work.

Licensability will be determined by establishment of the WFD Licensing strategy. Execution of this strategy along with preparation of a USQ evaluation of the WFD system against the existing TWRS Authorization Basis shall form the basis for licensability determination.

An environmental compliance task plan for the WFD System will establish the basis for permitability. This task plan outlines the preparation of a regulatory checklist which the WFD System can be compared to. The checklist establishes the applicable regulatory issues related to feed delivery, provides mitigating actions for issue resolution.

The attached outline identifies other issues to be reviewed such as decommissioning and cost. 
HNF-2403

Revision 0

This page intentionally left blank. 


\subsection{COMPOSITE RISK EVALUATION}

Risk evaluation can be performed in two facets. The first deals with risk encountered from construction activities. These risks are associated with the schedule to complete construction of the WFD system. The second facet is the ability to conduct process operations with the finished system. Construction risks will be reviewed with respect to the design details, the magnitude of the overall task, the affecting conditions (weather, resource availability, material availability, etc.) and the project control plan development (implementability). As discussed above, the project control plan will outline the sequence of construction activities and the relation of these activities to one another during the construction phase of the project.

Operability of the process will be evaluated based on the design and the processing expectations (which are developed with respect to the flowsheet and the Process design concept).

The RAM analysis is revisited after the constructability and operability issues are reviewed and RAM values are adjusted accordingly. A final risk evaluation is compiled and the appropriate measures are presented. These metrics are used to assign the overall risk associated with the WFD System. 
HNF-2403

Revision 0

This page intentionally left blank. 
HNF-2403

Revision 0

\subsection{REFERENCES}

Acree, C. D., 1998, Tank Waste Remediation System Mission Analysis Report, HNF-SD-WM-MAR-008, Rev. 0, Lockheed Martin Hanford Corporation, Richland, Washington.

Claghorn, R. D., 1998, Performance Requirements for the Double-shell Tank System: Phase 1, HNF-2168, Rev. 0, Numatec Hanford Corporation, Richland, Washington.

Claghorn, R. D., I. G. Papp, and B. B. Peters (MACTEC), 1998, Performance Requirements for Phase 1 Waste Feed Delivery Components, HNF-1985, Rev. 0, Numatec Hanford Corporation, Richland, Washington.

Freeman, D. V., 1998, Tank Waste Remediation System Program Plan, HNF-1883, Rev. 0, Lockheed Martin Hanford Corporation, Richland, Washington.

Kirkbride, R. A., G. K. Allen, P. J. Certa, A. F. Manuel, R. M. Orme, L. W. Shelton, E. J. Slaathaug, R. S. Wittman, and G. T. MacLean and D. L. Penwell (SESC), 1997, Tank Waste Remediation System Operation and Utilization Plan, HNF-SD-WM-SP-012, Rev. 0, Vol. I and II, Numatec Hanford Corporation, Richland, Washington.

LMHC, 1996, Tank Waste Remediation System Administration Manual, Lockheed Martin Hanford Corporation, Richland, Washington.

Swita, W. R., 1998, Tank Waste Remediation System Retrieval and Disposal Mission Initial Updated Baseline Summary, Lockheed Martin Hanford Corporation, Richland, Washington. 
HNF-2403

Revision 0

This page intentionally left blank. 
HNF-2403

Revision 0

APPENDIX A

\section{DOCUMENT OUTLINE}

PERFORMANCE REQUIREMENTS FOR

PHASE 1 WASTE FEED DELIVERY COMPONENTS 
HNF-2403

Revision 0

This page intentionally left blank. 
HNF-2403

Revision 0

\section{APPENDIX A}

\section{DOCUMENT OUTLINE \\ PERFORMANCE REQUIREMENTS FOR PHASE 1 WASTE FEED DELIVERY COMPONENTS}

3.1 Double-Shell Tank Farms

3.1.1 DST Structure

3.1.1.1 Intermediate Waste Feed Staging System

3.1.1.2 LAW Feed Source Tanks

3.1.1.3 HLW Feed Source Tanks

3.1.2 Instrumentation and Control (Tank Specific)

3.1.2.1 Intermediate Waste Feed Staging System

3.1.2.2 LAW Feed Source Tanks

3.1.2.3 HLW Feed Source tanks

3.1.3 DST HVAC

3.1.3.1 Intermediate Waste Feed Staging System

3.1.3.2 LAW Feed Source Tanks

3.1.3.3 HLW Feed Source Tanks

3.2 DST Transfer System

3.2.1 Decant Pump

3.2.1.1 Intermediate Waste Feed Staging tanks

3.2.1.2 LAW Feed Source Tanks

3.2.1.3 HLW Feed Source Tanks

3.2.2 Slurry Pump

3.2.3 Piping Network

3.2.3.1 Valving

3.2.3.2 Piping

3.2.4 Slurry Distributor

3.2.5 Master Pump Shutdown.

3.2.6 Supernatant Pump

3.3 Waste Preparation Equipment

3.3.1 Mixer Pumps

3.3.1.1 Intermediate waste Feed Staging System

3.3.1.2 LAW Feed Source Tanks

3.3.1.3 HLW Feed Source Tanks

3.3.2 Sonic Probes

3.3.3 Chemical Addition / Flushing System

3.3.3.1 Intermediate Waste Feed Staging Tanks

3.3.3.2 LAW Feed Source Tanks

3.3.3.3 HLW Feed Source Tanks 
HNF-2403

Revision 0

3.4 Monitor and Control System (Inter-farm)

3.4.1 Incermediate Waste Feed Staging Tanks

3.4.2 LAW Feed Source Tanks

3.4.3 HLW Feed Source Tanks

3.4.4 Other Systems

3.5 DST Utility Distribution System

3.5.1 Compressed Air

3.5.2 Potable Water

3.5.3 Raw Water

3.5.4 Electrical

3.5.4.1 Substations

3.5.4.2 Transformers

3.5.4.3 Motor Control Centers

3.5.5 Steam

3.5.6 Sewage

3.6 Maintenance and Recovery System 
HNF-2403

Revision 0

APPENDIX B

DOCUMENT OUTLINE

TECHNICAL BASIS DOCUMENT

B-1 
HNF-2403

Revision 0

This page intentionally left blank. 
HNF-2403

Revision 0

\section{APPENDIX B}

\section{DOCUMENT OUTLINE \\ TECHNICAL BASIS DOCUMENT}

VOLUME I - SUMMARY

THIS SECTION WILL INCLUDE A SUMMARY OF THE COMPLETE VOLUME SET. THE SUMMARY WILL PROVIDE CONDENSED AND EDITED SUBJECT MATTER FOR EXECUTIVE READING.

VOLUME II - WASTE FEED DELIVERY FLOWSHEET

\subsection{INTRODUCTION}

Each source tank is outlined with respect to the associated transfers required for staging and waste transfers (pages vary in length depending on the source tank).

\subsection{PROCESS SUMMARY}

The processing steps are outlined in relation to the requirements for treating waste in the source tank (2 paragraphs per source tank)

\subsection{LOW-ACTIVITY WASTE FEED STAGING (EACH SECTION BELOW VARIES IN LENGTH DEPENDING ON THE NUMBER OF STEPS APPLIED TO A PARTICULAR WASTE TRANSFER)}

\subsection{PROCESS DESCRIPTION}

Processing steps are detailed and related to the flowsheet tables developed for each source tank

\subsection{PROCESS TECHNOLOGY}

Discussion of the technology applied to treatment of specific waste

3.3 PROCESS CONTROL

Control parameters of specific process steps are discussed

3.4 RANGE OF OPERATIONS

Waste characteristics and properties are discussed to outline the physical state of the waste stream during transfer

3.5 EQUIPMENT DESCRIPTION

A summary description of information contained in Volume III

3.6 M\&I - CONTRACTOR INTERFACES

Material balances associated with transfers between the contractors facilities and the TWRS WFD system 
HNF-2403

Revision 0

\subsection{ESSENTIAL MATERIALS}

Discussion of materials (chemicals, utilities) needed to conduct process operations as depicted by the flowsheet tables

\subsection{HIGH-LEVEL WASTE FEED STAGING (EACH SECTION BELOW VARIES IN LENGTH DEPENDING ON THE NUMBER OF STEPS APPLIED TO A PARTICULAR WASTE TRANSFER)}

\subsection{PROCESS DESCRIPTION}

Processing steps are detailed and related to the flowsheet tables developed for each source tank

4.2 PROCESS TECHNOLOGY

Discussion of the technology applied to treatment of specific waste

4.3 PROCESS CONTROL

Control parameters of specific process steps are discussed

4.4 RANGE OF OPERATIONS

Waste characteristics and properties are discussed to outline the physical state of the waste stream during transfer

4.5 EQUIPMENT DESCRIPTION

A summary description of information contained in Volume III

4.6 M\&I - CONTRACTOR INTERFACES

Material balances associated with transfers between the contractors facilities and the TWRS WFD system

4.7 ESSENTIAL MATERIALS

Discussion of materials (chemicals, utilities) needed to conduct process operations as depicted by the flowsheet tables

\subsection{FLOWSHEET BASES}

Calculations, assumptions, etc. 
HNF-2403

Revision 0

VOLUME III - WASTE FEED DELIVERY PROCESS DESIGN CONCEPT

\subsection{INTRODUCTION}

Brief overview of volume III info and statement of intent

\subsection{SYSTEM OVERVIEW}

2.1 Double-Shell Tank Farms

2.1.1 DST Structure

2.1.1.1 Intermediate Waste Feed Staging System

2.1.1.2 LAW Feed Source Tanks

2.1.1.3 HLW Feed Source Tanks

2.1.2 Instrumentation and Control (Tank Specific)

2.1.2.1 Intermediate Waste Feed Staging System

2.1.2.2 LAW Feed Source Tanks

2.1.2.3 HLW Feed Source tanks

2.1.3 DST HVAC

2.1.3.1 Intermediate Waste Feed Staging System

2.1.3.2 LAW Feed Source Tanks

2.1.3.3 HLW Feed Source Tanks

2.2 DST Transfer System

2.2.1 Decant Pump

2.2.1.1 Intermediate Waste Feed Staging tanks

2.2.1.2 LAW Feed Source Tanks

2.2.1.3 HLW Feed Source Tanks

2.2.2 Slurry Pump

2.2.3 Piping Network

2.2.3.1 Valving 
HNF-2403

Revision 0

2.2.3.2 Piping

2.2.4 Slurry Distributor

2.2.5 Master Pump Shutdown

2.2.6 Supernatant Pump

2.3 Waste Preparation Equipment

2.3.1 Mixer Pumps

2.3.1.1 Intermediate waste Feed Staging System

2.3.1.2 LAW Feed Source Tanks

2.3.1.3 HLW Feed Source Tanks

2.3.2 Sonic Probes

2.3.3 Chemical Addition / Flushing System

2.3.3.1 Intermediate Waste Feed Staging Tanks

2.3.3.2 LAW Feed Source Tanks

2.3.3.3 HLW Feed Source Tanks

2.4 Monitor and Control System (Inter-farm)

2.4.1 Intermediate Waste Feed Staging Tanks

2.4.2 LAW Feed Source Tanks

2.4.3 HLW Feed Source Tanks

2.4.4 Other Systems

2.5 DST Utility Distribution System

2.5.1 Compressed Air

2.5.2 Potable Water

2.5.3 Raw Water

2.5.4 Electrical

2.5.4.1 Substations

2.5.4.2 Transformers

2.5.4.3 Motor Control Centers

2.5.5 Steam

B-6 
HNF-2403

Revision 0

2.5.6 Sewage

2.6 Maintenance and Recovery System

\subsection{PROCESS ENGINEERING CALCULATIONS}

Calculations are discussed in reference to establishing an envelope suitable for transfer operations. Appendix material contains actual calculations. The following calculations are provided as they apply to each source tank and staging tank transfer. The following list may not be all inclusive of every calculation performed for a particular transfer.

3.1 SOLIDS VOLUME DETERMINATION

3.2 DEPOSITION VELOCITY

3.3 PRESSURE DROP IN THE TRANSFER LINE

3.4 VISCOSITY INVESTIGATION AS RELATED TO REYNOLD $=S$ NUMBER

3.5 FLUIDIZATION OF A PARTICLE

3.6 WATER HAMMER EVALUATION

\subsection{SAFETY AND LICENSING}

System performance is evaluated in relation to requirements set forth by the authorization basis. This discussion is in conjunction with the USQ evaluation.

\subsection{ENVIRONMENTAL}

The specific environmental considerations are discussed in relation to permitting activities. This discussion is in conjunction with the environmental permitting plan, permit application, and related engineering studies which support WFD.

\subsection{DRAWINGS}

The following drawings are provided as they relate to the respective transfers. Other drawings may be added as necessary to complete the required configuration management of the WFD System.

6.1 AREA MAP

Provides the coordinates of the transfer paths in relation to the source and receiver tanks.

6.2 P\&IDs

Details of the piping and instrumentation are for specific areas of the WFD System. Drawings will be comprehensive of the WFD System.

6.3 HYDRAULIC

Provide a hydraulic profile of the WFD System to account for elevation differences between system components. 
HNF-2403

Revision 0

\subsection{HIGH-LEVEL WASTE TRANSFER}

Illustration of specific high-level waste transfer paths. A drawing will be provided in a simplified P\&ID fashion to depict the entire transfer path from specific source tanks to receiver tanks.

\subsection{LOW-ACTIVITY WASTE TRANSFER}

Illustration of specific low-activity waste transfer paths. A drawing will be provided in a simplified P\&ID fashion to depict the entire transfer path from specific source tanks to receiver tanks. 
HNF-2403

Revision 0

WASTE FEED DELIVERY TECHNICAL BASIS DOCUMENT VOLUME IV, OPERATIONS AND MAINTENANCE CONCEPT

\subsection{INTRODUCTION}

- Definition and purpose of Operation and Maintenance (O\&M) concept

- Summary and relationships to other volumes/documents

- Requirements

2.0 WASTE FEED DELIVERY FUNCTIONS

3.0 SYSTEMS, STRUCTURES, AND COMPONENTS

3.1 WASTE FEED DELIVERY OPERATING SUBSYSTEMS

3.2 BASIS FOR MAINTENANCE PLANNING

3.2.1 Safety Equipment (Existing and Proposed)

3.2.2 Spare Parts (Existing and Proposed)

3.2.3 Other Risk-Significant Equipment (Existing and Proposed)

4.0 OPERATION AND MAINTENANCE STRATEGY

4.1 OPERATIONS AND PROCESS CONTROL STRATEGY

4.2 MAINTENANCE STRATEGY

4.3 ENVIRONMENTAL, SAFETY, HEALTH, AND QUALITY COMPLIANCE STRATEGY 
HNF-2403

Revision 0

\subsection{MANAGEMENT OVERSIGHT STRATEGY}

\subsection{OPERATING MODES}

\subsection{NORMAL OPERATIONS}

Table for each major function (e.g., prepare and stage feed) including associated operating steps, and for each step, the subsystems employed, staff types and numbers required, and the high, low, and expected times required to execute the steps with conditions and assumptions defined for the times.

\subsection{OFF-NORMAL RECOVERY}

Tables for each off-normal condition including associated recovery steps, and for each step, the subsystems employed, staff types and numbers required, and high, low, and expected times required to execute the steps with conditions defined for the times.

\subsection{MANTENANCE MODES}

\subsection{NORMAL MAINTENANCE DURING OPERATIONS}

Tables showing normal calibrations and preventative maintenance steps for selected "basis-for-maintenance-planning" equipment element, staff types and numbers required to complete maintenance, high, low, and expected times to completed maintenance/recovery, and conditions/bases for the times.

\subsection{EQUIPMENT FAILURE/RECOVERY}

Table showing steps for repair/restoration each failed equipment element, staff types and numbers required to complete maintenance, high, low, and expected times to complete maintenance/recovery, and conditions/bases for the times.

\subsection{OPERATION AND MAINTENANCE LOGIC DIAGRAMS}


HNF-2403

Revision 0

APPENDIX C

RAM ANALYSIS OUTLINE

C-1 
HNF-2403

Revision 0

This page intentionally left blank.

C-2 
HNF-2403

Revision 0

APPENDIX C

RAM ANALYSIS OUTLINE

\subsection{INTRODUCTION}

The overall approach will be to build on the work already accomplished by the Tanks Waste Remediation System (TWRS) organization. A graded approach will assist the operating elements to give priority to functions and tasks that enhance the overall operational availability of the TWRS delivery system for meeting the requirements of the privatization agreements. This will be done by formulating operational availability figures of merit and supporting metrics that can be used to analyze raw and processed data generated during O\&M activities and assist TWRS personnel to anticipate potential problems.

\subsection{Program Overview}

\subsection{Program Objectives}

\subsection{RAM ANALYSIS APPROACH}

A general approach for RAM analysis is presented as follows:

2.1 Define the facility(ies) and/or process(es) to be analyzed.

\subsection{Define specific process functions.}

\subsection{Define functional boundaries for analysis.}

In this step, the RAM analysis team defines and refines the boundaries of the process functions. This involves definition of specific functional process steps and associated timing/scheduling of these steps in the overall facility process. The steps are generally best defined via the use of a process time line or time-based logic diagram. At TWRS, project logic diagrams and the TWRS logic simulation model are good examples of tools which support the clear definition of functional boundaries. 


\subsection{Define hardware boundaries for analysis.}

Subsequent to the definition of functional boundaries, the RAM analysis team identifies hardware and specific procedural boundaries for the analysis. The hardware boundaries should be specific, generally identified by designated pipe flanges or weld boundaries, valve flanges or weld boundaries, pump flanges or weld boundaries, junctions with tanks, electrical breaker connections, circuit lead connections, instrument lead connections, etc.

\subsection{Define non-hardware boundaries (procedural, staffing, etc.) boundaries for analysis.}

Next, specific procedural steps for required human actions associated with the process functions are defined, and boundaries within these procedures identified as they relate to the RAM analysis. Any staffing requirements associated with the required human actions during the process are also defined.

\subsection{Define appropriate RAM figures of merit (metrics).}

While all the steps identified in this general RAM analysis approach are actually performed in an iterative manner, this point in the process has proven to be a good juncture to identify specific RAM figures of merit to aid in O\&M decision-making for the facility process and its supporting functions. These figures of merit are often termed as the "metrics" for program decision-making. In this project, the preliminary metrics identified are the relative frequency of failure of specific TWRS WFD evolutions, and the risk of schedule delay associated with specific failure scenarios. Other potential metrics are overall TWRS operational availability, system time-based failure frequency, and system level mean time to restore operation following failure. Other figures of merit include component contribution to overall schedule delay risk, component failure rates and demand failure probabilities, and component mean time to restore function following failure.

\subsection{Define process, function, system, subsystem, and component success criteria.}

Using information from previous steps in the RAM analysis process, the RAM team defines specific criteria for the success of process evolutions and supporting functions and hardware. The functional, hardware, and human action success criteria are defined at the system, subsystem, and component levels of indenture. The human action success criteria are related to specific procedural steps supporting the facility process.

\subsection{Define process, function, system, subsystem, and component problem and failure modes and potential effects.}

Next, the RAM team performs a problem/failure modes and effects analysis on the entire facility process. This failure modes and effects analysis (FMEA) can be performed at the system, subsystem, and/or component level of indenture, but generally is most effective if developed down to the component level of indenture, or at least the fundamental process element at a level most likely to define efficient maintenance, repair, or process improvement. 
HNF-2403

Revision 0

\subsection{Develop process/system RAM logic model(s).}

Next, the RAM team develops RAM logic models. These models can be developed in the form of reliability or availability block diagrams showing the series and parallel logic required for system success; event trees defining scenarios which could lead to process failure; and/or fault trees identifying the series and parallel logic of specific component and human action failures which could lead to a pre-defined system failure. The reliability/availability block diagrams are developed in ?success space,? while the fault trees are developed in ?failure space.? The event trees show both success and failure paths in the process, but generally focus on the possible failure scenarios.

\subsection{Collect/process RAM data.}

The RAM team then collects RAM data to calculate fundamental parameters for RAM logic model quantification, supporting calculation of predicted RAM metrics. RAM data includes time-based or ?running? failure rates, demand-based failure probabilities, and associated repair and restoration times for failure modes identified in previous steps of the RAM analysis process. This step also includes collection of component success data and exposure time. The success information is equally important to the failure data collected. The collection and analysis of RAM data includes both the collection of industry generic data on similar components and human actions, and TWRS specific historical RAM performance data. The data are generally organized in a project RAM relational database.

\subsection{Perform baseline RAM analysis.}

In this portion of the RAM analysis the RAM data is ?married? with the RAM logic models to quantify RAM figures of merit or metrics. The first quantification is performed on a baseline case with well-defined analysis bases and assumptions. The results form the baseline RAM metrics for subsequent comparison to improvement option case studies and to support associated RAM management and O\&M decision-making. The baseline analysis includes calculation of individual component and human action failure/restoration contribution to overall system availability and schedule delay risk. The component and human action contributions can be used to develop critical items lists of components and human actions prioritized based on their contributions to RAM and associated risk.

\subsection{Identify potential improvement options.}

The prioritized critical items lists along with detailed knowledge of system success criteria can then be used by the RAM team to develop recommendations for RAM and O\&M improvement. These improvement options could include component replacements with more reliable designs, improved maintenance training and practices for reduction of restoration time, and recommendations for human action procedure improvement and training focus. In general, the RAM results can be used to make recommendations for cost-effective allocation of resources to manage risk and optimize RAM and safety performance. 
HNF-2403

Revision 0

2.13 Perform RAM case studies analyzing improvement options.

After the RAM improvement options have been identified, RAM case studies are developed to analyze the potential effectiveness of various individual RAM improvement options and groups or ?packages? of improvement options. The resulting RAM metrics are presented in comparative tables and charts.

\subsection{Make implementation recommendations to process management.}

The metrics from various RAM case studies are used to support the formulation of specific recommendations for implementation of RAM improvements and other general improvements to facility process management. PLG experience shows that the depth of knowledge of the process and associated hardware and procedures gained from performing a rigorous RAM analysis pays valuable dividends in providing improvement option implementation guidance and insight.

\subsection{Collect and analyze feedback information for future case studies.}

As the RAM improvement options are implemented, the RAM team collects RAM (failure and success) data to track and trend facility RAM performance and provide feedback for continuous improvement throughout the facility life cycle. This data can be used to develop additional RAM improvement options and form the bases for new RAM improvement case studies.

2.16 Perform iterative continuous improvement of the RAM analysis throughout the facility/process life cycle.

The process described in the previous steps of the RAM analysis and management approach are continued throughout the facility life cycle to promote continuous RAM improvement and schedule delay risk management.

\subsection{RAM ANALYSIS PROJECT TASKS}

The TWRS RAM analysis project tasks are defined as follows:

\subsection{Define Specific RAM Measures}

The results of this task will be used to develop high-level RAM measures that will identify key transition points and success criteria within the current planned processes. The objective is to construct a RAM figure-of-merit that will provide information at the key points in the process where decisions to proceed must be made. 
HNF-2403

Revision 0

\subsection{Prepare Preliminary RAM Allocation Model}

PLG will begin to examine the dynamic process model for opportunities to define RAM modeling characteristics for the TWRS processes. PLG has developed computer programs, such as RISKMAN ${ }^{?}$, QUICKRAM, and STADIC, that can analyze and evaluate RAM logic models and that can apply probability distributions for uncertainty parameters and perform structured Monte Carlo simulations. These programs have been shown to be extremely valuable for promoting a clear understanding of the impacts of combinations of RAM parameters resultant scenarios of physical outcomes

\subsection{Consolidate and Integrate Available RAM Data}

The RAM data and associated risk information will be organized and tracked in an appropriate relational database structure, such as Microsoft Access. The structure will be designed to trend and display information that will be useful to decision-makers. The structure will be simple, but flexible to support providing insight for management action during changing situations at TWRS. The database structure will be designed to make maximum use of existing tools, such as the TWRS Programmatic Risk Information Management System (PRIMS) and/or other supporting database.

\subsection{Perform RAM/Schedule Risk Analysis}

Based on the O\&M Concepts information and RAM data generated in the prior Tasks, PLG will perform RAM and related risk analyses to support the TWRS program in developing a safe, reliable, cost-effective waste feed delivery system. These analyses will characterize the existing plans and designs, assist in developing reliability and maintainability goals, recommend areas of RAM and risk performance improvement, assist in ensuring operational flexibility, support operations and maintenance basis planning, support logistics planning, and support future readiness activities.

\subsection{Develop Operational Availability $\left(\mathbf{A}_{0}\right)$ Figure of Merit (FOM)}

Using input from developing the RAM/risk analysis, a rough order of magnitude, expected total availability figure-of-merit will be developed. This figure-of-merit will be a primary calculated output from the RAM analysis. The assessment will identify the total expected operating availability for the proposed WFDS. To the extent possible, the figure-of-merit will be defined in terms that relate directly to the anticipated operation of the TWRS systems.

\subsection{PRODUCT DELIVERABLES}

\subsection{RAM Metrics with Associated Bases and Assumptions}

The RAM metrics at the overall process system level are: success and failure probabilities of 
HNF-2403

Revision 0

problem/failure-free TWRS WFD evolution performance; Potential schedule delay time associated with the minimum time required for successful TWRS WFD evolution performance; Potential schedule delay time associated with the scheduled time required for successful TWRS WFD evolution performance as defined in TWRS logic diagrams; Time-based frequency of TWRS WFD process failure based on the current schedule defined in the TWRS logic diagrams; and Mean restoration time for TWRS WFD evolution failure scenarios. At the component level, the RAM metrics are time-based failure frequency for running failures, demand-based failure probability for standby/demand failures, and component mean time to restore. All mean time to restore values include administrative down time, logistics time, and parts procurement time, as well as actual repair action time. At the human action level, the RAM metrics are human error rate per demand for action and mean human error recovery time.

\subsubsection{Top Level RAM Information Relational Database}

The RAM relational database is presented herein in preliminary format in Appendix B of this report. The data record fields are self-explanatory.

\subsubsection{Preliminary Baseline RAM Logic Model}

These models are presented as tiered availability logic diagrams, developed in success space, that is, any interruption in the logic flow from left to right, top to bottom, will fail or delay the TWRS WFD process.

\subsubsection{Initial Case Study Preliminary Results}

Initial case study results are presented in Appendix C of this report.

\subsection{EXAMPLE HIGH-LEVEL CASE STUDIES}

\subsection{TWRS RAM Figures of Merit}


HNF-2403

Revision 0

The RAM metrics at the overall process system level are: success and failure probabilities of problem/failure-free TWRS WFD evolution performance; Potential schedule delay time associated with the minimum time required for successful TWRS WFD evolution performance; Potential schedule delay time associated with the scheduled time required for successful TWRS WFD evolution performance as defined in TWRS logic diagrams; Time-based frequency of TWRS WFD process failure based on the current schedule defined in the TWRS logic diagrams; and Mean restoration time for TWRS WFD evolution failure scenarios. At the component level, the RAM metrics are time-based failure frequency for running failures, demand-based failure probability for standby/demand failures, and component mean time to restore. All mean time to restore values include administrative down time, logistics time, and parts procurement time, as well as actual repair action time. At the human action level, the RAM metrics are human error rate per demand for action and mean human error recovery time.

\subsection{Baseline Cases(s)}

The preliminary RAM analysis baseline case study results are presented in Appendix $\mathbf{C}$ of this report. The baseline cases are identified below:

\subsubsection{AN 104 Transfer (All Batches)}

\subsubsection{AN 105 Transfer (All Batches)}

\subsubsection{AZ 101 Transfer (All Batches)}

\subsection{POTENTIAL INTERFACES WITH TWRS DECISION MANAGEMENT SYSTEMS}

Potential interfaces of the RAM/Schedule Risk Analysis Products and associated insights are presented as follows:

\subsection{Key Input to Project Management/Scheduling Process (i.e., Primavera Scheduling)}

\subsection{Input for TWRS Configuration Management Program}

\subsection{Input for Retrieval Decision Logic}

\subsection{Key Input to Operational Milestones}

\subsection{Input for New Equipment Design/Procurement}

\subsection{Input for Spare SOW Parts Procurement/Inventory Management}

\subsection{Input for TWRS Staffing Management}


HNF-2403

Revision 0

6.8 Input for Operations Procedure Development

6.9 Input for Maintenance Procedure Development

6.10 Input for Equipment Test Policies and Programs

6.11 Input for Operations and Maintenance Training and Qualification Programs

6.12 Input for TWRS Cost-Benefit-Risk Analyses/Economic Management

6.13 Input for Readiness Review Criteria/Performance Measurement

\subsection{REFERENCES}

\section{APPENDIX A ? RAM LOGIC MODELS}

APPENDIX B ? RAM DATABASE

APPENDIX C ? PRELIMINARY RAM ANALYSIS CASE STUDY RESULTS 
HNF-2403

Revision 0

\section{APPENDIX D}

WASTE FEED DELIVERY SYSTEM (WFDS) COMPOSITE RISK ANALYSIS

DRAFT OUTLINE

D-1 
HNF-2403

Revision 0

This page intentionally left blank.

\section{D-2}


HNF-2403

Revision 0

\title{
APPENDIX D
}

\section{WASTE FEED DELIVERY SYSTEM \\ COMPOSITE RISK ANALYSIS}

\author{
DRAFT OUTLINE
}

\section{EXECUTIVE SUMMARY}

\subsection{INTRODUCTION}

A general description of the risk analysis purpose, scope, and general approach will be provided. The structure of the report will be described.

\subsection{DESCRIPTION OF RISK ANALYSIS METHODOLOGIES}

The general risk evaluation method will be a system review by Hanford Site subject matter experts. Each of the risk category reviews will be structured similarly (to the extent possible) and the results will be expressed in a form which will allow some comparison between categories.

\subsection{CONSTRUCTHILITY RISK METHODOLOGY}

\subsubsection{Performance Criteria and Discriminators} listed from the WFD Equipment Decision Plan \& Criteria

2.1.2 Methods Used to Evaluate Risk A description of the particular method(s) used to compare the proposed system against the performance criteria and discriminators. The method will result in a semi-quantitative rating of the risk of not meeting the specified criteria.

\subsection{OPERABILITY RISK METHODOLOGY}

2.2.1 Performance Criteria and Discriminators

2.2.2 Methods Used to Evaluate Risk

2.3 PROCESSABILITY RISK METHODOLOGY

2.3.1 Performance Criteria and Discriminators

2.3.2 Methods Used to Evaluate Risk

2.4 PERMITABILITY RISK METHODOLOGY

2.4.1 Performance Criteria and Discriminators

2.4.2 Methods Used to Evaluate Risk

2.5 SAFETY/LICENSING RISK METHODOLOGY

2.5.1 Performance Criteria and Discriminators

2.5.2 Methods Used to Evaluate Risk

2.6 DECONTAMINATION, DECOMMISSIONING, AND DISPOSAL RISK METHODOLOGY

2.6.1 Performance Criteria and Discriminators

2.6.2 Methods Used to Evaluate Risk

2.7 COST METHODOLOGY

2.7.1 Performance Criteria and Discriminators 
HNF-2403

Revision 0

\subsubsection{Methods Used to Evaluate Cost}

\subsection{BASES AND ASSUMPTIONS (3-10 pages)}

Evaluation of each of the different risk categories will require that various assumptions be made. These assumptions and their bases will be documented in this section.

\subsection{SUMMARY OF RISKS}

The results of each risk evaluation will be documented in the following sections. The first section addresses whether the proposed system design is constructable and the construction schedule risk. The second and third sections assess whether the proposed systems are operable (human factors) and can successfully process the waste (mechanical/chemical) to meet contractual requirements. The fourth and fifth section address issue related to obtaining permits and licenses and safety. Risks associated with the ability to D\&D and dispose the system after the mission is complete are discussed in the sixth section. Only a summary of the RAM analysis is provided in the seventh section. The RAM analysis is a separate effort (doc. B) which will assess schedule risk associated with SSC failures. A basic assumption of the RAM analysis is that the system will be properly designed and that appropriate systems and O\&M processes will be in place. The risks discussed above address various aspects of this assumption.
4.1 CONSTRUCTABUITY
4.2 OPERABILITY
4.3 PROCESSABILITY
4.4 PERMITABILITY
4.5 SAFETY/LICENSING
4.6 DECONTAMINATION, DECOMMISSIONING, AND DISPOSAL
4.7 RELIABILITY, AVALLABILITY, MAINTAINABILITY (RAM)
4.8 COSTS

\subsection{COMPOSITE RISK EVALUATION}

The various aspects of risk are composited to provide a comparison of the balance of risks, i.e. are certain risks very high and others low, and can the problem be corrected by changing the design concept or the O\&M concept. Each of the components of the overall programmatic risk will be expressed in different terms and the programmatic tolerance for each of the risks will vary. Development of the composite risk will require close interaction with program management.

\subsection{CONCLUSIONS/RECOMMENDATIONS}

Recommendations regarding potential changes to the baseline system to reduce or mitigate the risks will be provided, based on the magnitude and balance of risks. 


\section{DISTRIBUTION SHEET}

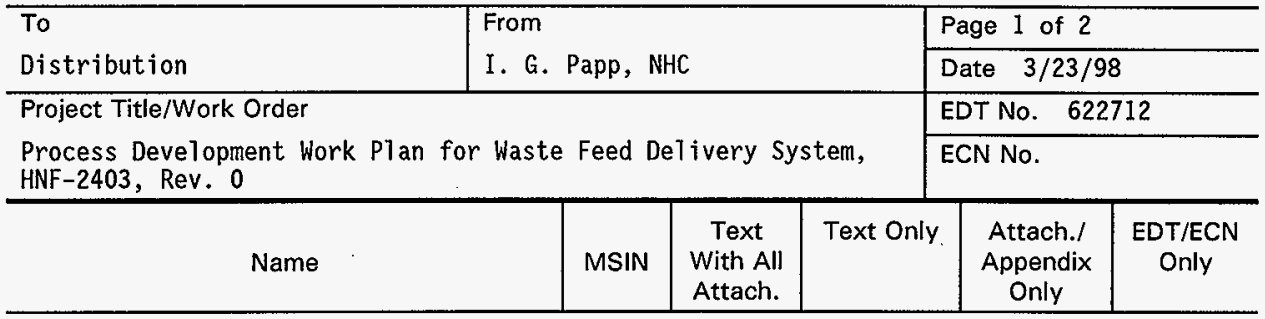

Central Files

DOE Reading Room

M. G. AT-Wazani

J. J. Badden

S. K. Baker

L. Bedford

T. M. B] aak

K. A. Boes

D. E. Bowers

V. C. Boyles

D. A. Bragg

W. G. Brown

W. E. Bryan

J. G. Burton

P. J. Certa

T. Choho

R. A. Claghorn

D. W. Crass

G. Cummings

T. W. Crawford

M. L. Deffenbaugh

J. N. Doeler

L. A. Domnoske-Rauch

K. E. Drakulich

W. F. Erbe

M. F. Erhart

S. D. Estey

B. K. Everett

K. J. Freeman

J. D. Galbraith

J. S. Garfield

M. S. Garrett

G. J. Gauck

P. A. Haine

0 . A. Halverson

D. Hammond

J. P. Harris III

W. M. Harty

D. B. Higham

K. M. Hodgson

J. H. Huber

K. J. Hul1

M. N. Johnson

B1-07 $X$

A1-65 $X$

T4-07 $X$

T4-07 $X$

H5-49 $X$

R2-84 X

S5-13 $X$

R3-25 X

S5-13 $X$

R2-11 $X$

S5-05 $x$

T4-07 $X$

S5-05 $x$

S7-21 $X$

H5-61 $X$

R3-47

H5- 49

R3-47

S4-49

H5- 49

H6-37

T4-07

S5-13

T4-01

S5-05

R1-56

R2-11

S5-05

T4-00

H5-49

H5- 49

T4-07

T4-07

R3-47

G3-21

R1-44

R1-49

55-13

T4-00

R2-11

T4-07

T4-07

S8-05

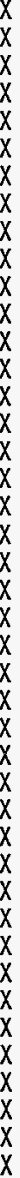




\section{DISTRIBUTION SHEET}

\begin{tabular}{|c|c|c|c|c|c|}
\hline \multirow{2}{*}{$\begin{array}{l}\text { To } \\
\text { Distribution }\end{array}$} & \multirow{2}{*}{\multicolumn{3}{|c|}{$\begin{array}{l}\text { From } \\
\text { I. G. Papp, NHC }\end{array}$}} & \multicolumn{2}{|l|}{ Page 2 of 2} \\
\hline & & & & \multicolumn{2}{|c|}{ Date $3 / 23 / 98$} \\
\hline \multirow{2}{*}{\multicolumn{4}{|c|}{$\begin{array}{l}\text { Project Title/Work Order } \\
\text { Process Development Work P1 an for Waste Feed Delivery System, } \\
\text { HNF-2403, Rev. } 0\end{array}$}} & \multicolumn{2}{|c|}{ EDT No. 622712} \\
\hline & & & & \multicolumn{2}{|l|}{ ECN No. } \\
\hline Name & MSIN & $\begin{array}{l}\text { Text } \\
\text { With All } \\
\text { Attach. }\end{array}$ & Text Only & $\begin{array}{l}\text { Attach./ } \\
\text { Appendix } \\
\text { Only }\end{array}$ & $\begin{array}{c}\text { EDT/ECN } \\
\text { Only }\end{array}$ \\
\hline
\end{tabular}

J. M. Jones

T. D. Kaiser

L. R. Kiewert

N. W. Kirch

R. A. Kirkbride

P. F. Kison

J. R. Kriskovich

D. L. Lamberd

T. Laney

R. E. Larson

J. Lohrasbi

R. P. Marshall

P. C. Miller

J. M. Morris

R. L. Netson

R. S. Nicholson

D. R. Nunamaker

R. M. Orme

S. M. O'Toole

I. G. Papp (2)

L. G. Peck

D. L. Penwe11

R. D. Potter

W. J. Powell

R. L. Powers

0 . R. Rasmussen

D. W. Reberger

R. W. Reed

D. A. Reynolds

C. A. Rieck

D. J. Saueressig

J. S. Schofield

E. J. Slaathaug

D. W. Strasser

M. J. Sutey

G. R. Tardiff

W. T. Thompson

R. P. Tucker

J. E. VanBeek

J. E. Wells

K. A. White

W. L. Willis

R. S. Wittman

W. F. Zuroff

\section{S5-13}

T4-07

S5-05

R2-11

H5-49

T4-07

R1-56

H5-61

S5-05

T4-07

S5-05

H5-61

T4-08

R2-87

R3-47

S5-05

T4-07

H5-27

G3-21

H5-49

H6-35

H5-49

H5-03

S5-13

S5-13

R1-51

S5-13

T4-07

R2-11

S2-48

S8-05

S7-12

H5-49

T4-00

T4-08

S5-05

G3-21

T4-01

S2-48

S5-05

S5-13

H5-61

H5- 49

S8-05.
$X$
$X$
$X$
$X$
$X$
$X$
$X$
$X$
$X$
$X$
$X$
$X$
$X$
$X$
$X$
$X$
$X$
$X$
$X$
$X$
$X$
$X$
$X$
$X$
$X$
$X$
$X$
$X$
$X$
$X$
$X$
$X$
$X$
$X$
$X$
$X$
$X$
$X$
$X$
$X$
$X$ 